Editorial

\title{
A TIME FOR DECISION
}

Thousands of civilians were killed or wounded by mines during the conflict in Afghanistan and their number has continued to rise since the end of the conflict, now that refugees are trying to return home. Thousands of children have been maimed, have had limbs amputated and been disabled for life. Using current mine-clearing techniques, it would take 4,300 years to render only twenty per cent of Afghan territory safe - a statistic which conveys an immense feeling of helplessness in the face of such an unprecedented disaster.

This tragic picture which the delegates of the Afghan Red Crescent Society described, amidst deep silence, to the participants at the Council of Delegates in Birmingham last October and the detailed reports by the National Societies - especially from those countries which have to live with this horror day after day - lent a sombre tone to the work of the Council of Delegates; indeed the very depth of that silence conveyed the Movement's concern over the gravity of current events in the world and, particularly, the magnitude of its task in combatting the unacceptable or, even worse, the trivialization of evil.

However, within the Movement there is no room for compassion fatigue, according to the words of Her Majesty Queen Elizabeth II, the Patron of the British Red Cross, who honoured the meeting with her presence. It must continue to protect and assist victims, come what may, like the volunteer workers of the Somali Red Crescent Society which was awarded the Red Cross and Red Crescent Prize for Peace and Humanity in recognition of the remarkable work it accomplished during the hostilities and famine in Somalia. The Council of Delegates also paid due tribute to the volunteer workers of many National Societies and congratulated the ICRC and Federation delegates on their humanitarian achievements.

It may have been the fact that several dedicated and courageous delegates and volunteers had lost their lives or been injured in the 
course of duty that spurred the Council to show greater determination, in its discussions and conclusions, to denounce those responsible for grave breaches of humanitarian law and mobilize governments to put the Final Declaration of the International Conference for the Protection of War Victims into practice. While it urged States to seek effective means of stopping the indiscriminate use of mines and called on them to do so at the forthcoming Review Conference on the 1980 United Nations Convention on Prohibitions or Restrictions on the Use of Certain Excessively Injurious Weapons, it also encouraged the National Societies, the ICRC and the Federation to intensify their efforts to provide means, equipment and staff for the medical treatment and rehabilitation of mine victims.

Some States, disregarding the basic rules of humanitarian treaties, do nothing to prevent children from being recruited and supplied with weapons during armed conflicts. The Council therefore asked the National Societies to encourage their respective governments to ratify the Convention on the Rights of the Child; it also requested the ICRC and the Federation to implement a Plan of Action aimed at promoting the principle of non-recruitment and non-participation of children below the age of eighteen in armed conflicts and to take concrete action to protect and assist child victims of such conflicts.

Furthermore, many Council resolutions point to the need to maintain the true purpose of humanitarian work, i.e. to serve the interests of the victims and their interests alone. To this end, the Council considered it appropriate to stress that humanitarian assistance is governed by principles which stipulate both the duties of States and the rights of victims and humanitarian organizations. It also considered that it would be useful for organizations engaged in disaster relief operations, whatever the cause of the disaster, to comply with a Code of Conduct approved by the Council; this Code will have to be submitted for approval by the main humanitarian organizations involved in emergency assistance operations.

It is becoming imperative to include tolerance as part of educational programmes if the rise in xenophobia and racial or ethnic discrimination is to be effectively curbed, especially in countries receiving refugees and asylum seekers. It is vital that the Movement's Fundamental Principles be understood and respected as an ethical charter for the Red Cross and Red Crescent; teaching of the Principles and of international humanitarian law must be intensified so as to reach all sectors of the public, with special emphasis on military personnel. According to Mr. Sommaruga, who chaired the meeting, a 
greater impetus must undoubtedly be given to dissemination in order to attain a culture based on solidarity and tolerance.

Can the Council of Delegates improve upon and obtain consensus in the dialogue that is so essential between all the components of the Movement? The latest meeting, which was extremely well organized by the British Red Cross, is perhaps a promising indication, to judge by the importance of the subjects dealt with and the active participation by a high number of National Societies from all parts of the world. This aspect will have to be looked into again when examining the entire set of recommendations put forward by the Study Group on the Future of the Red Cross and Red Crescent Movement. The meeting devoted much attention to the report of this Group. As the year 2000 approaches, the Movement must ponder on its future and adapt to the realities of a constantly changing world; at the same time, it must retain its own specific character and adhere to its Fundamental Principles to ensure that it works for the disadvantaged as effectively and consistently as possible.

These recommendations for the Movement, which are "evolutionary and not revolutionary", will be studied by a Policy and Planning Advisory Commission. A long and uphill task, but a necessary one, if the Movement is to adapt successfully and be able to face the challenges of the third millennium in an open, confident and self-assured manner.

The Review 